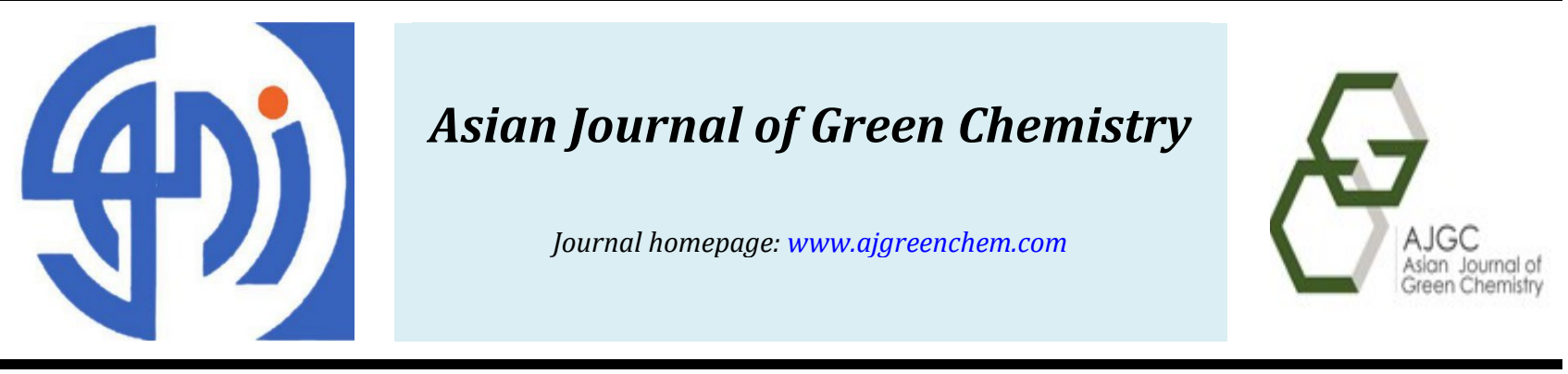

Original Research Article

\title{
Synthesis and anti-microbial activities of azomethine and aminomethyl phenol derivatives
}

\author{
Sivakumar Matama, Prabakaran Kaliyana, Padmavathy Sethuramasamyb, \\ Seenivasa Perumal Muthua,* (D)
}

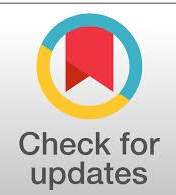

a Department of Chemistry, The Gandhigram Rural Institute-Deemed to be University, Gandhigram, Dindigul district, Tamilnadu-624 302, India

b Department of Zoology and Microbiology, Thiagarajar College, Madurai, Tamil Nadu, India

\section{ARTICLE INFORMATION}

Received: 25 September 2018

Received in revised: 19 December 2018

Accepted: 20 December 2018

Available online: 29 Jauary 2019

DOI: $10.33495 / S A M I / A J G C / 2019.4 .7$

\section{KEYWORDS}

Aldehyde

Azomethines

Aminomethyl phenol

Antibacterial activity

Antifungal activity

\begin{abstract}
A series of azomethine and aminomethyl phenol derivatives was synthesized, and characterized using mass, IR, and NMR spectral techniques. In vitro antimicrobial activities of the compounds were evaluated against different gram-positive and gram-negative bacterial and fungal strains by measuring zone of inhibition using agar diffusion method. Results of the antimicrobial screening indicated that the compound $\mathbf{4 a}$ was the most active antimicrobial agent $(100 \mu \mathrm{g} / \mathrm{mL})$. The compounds $3 \mathbf{3 a}, \mathbf{4 e}, \mathbf{4 f}$ were exhibited best in vitro anti-microbial activity against the gram positive bacterial strains such as Bacillus subtilis, Micrococcus luteus and gram negative bacterial strain Salmonella typhi, and fungal strain Candida albicans.

(C) 2019 by SPC (Sami Publishing Company), Asian Journal of Green Chemistry, Reproduction is permitted for noncommercial purposes.
\end{abstract}

\section{Graphical Abstract}

$$
\begin{aligned}
& \mathrm{Ar}_{\mathrm{H}}^{\mathrm{O}} \stackrel{\text { 1. } \mathrm{Ar}^{\prime}-\mathrm{NH}_{2}, \mathrm{EtOH}}{2 . \mathrm{NaBH}_{4}, \mathrm{EtOH}} \mathrm{Ar} \\
& \mathrm{Ar}=2-\mathrm{OH}-\mathrm{C}_{6} \mathrm{H}_{4} \\
& \mathrm{Ar}=-\mathrm{C}_{6} \mathrm{H}_{5},-4-\mathrm{MeC}_{6} \mathrm{H}_{4}, \\
& -4-\mathrm{OMeC}_{6} \mathrm{H}_{5},-\mathrm{NC}_{6} \mathrm{H}_{4},-4-\mathrm{ClC}^{-} \mathrm{H}_{5}, 4-\mathrm{NO}_{2} \mathrm{C}_{6} \mathrm{H}_{4}
\end{aligned}
$$

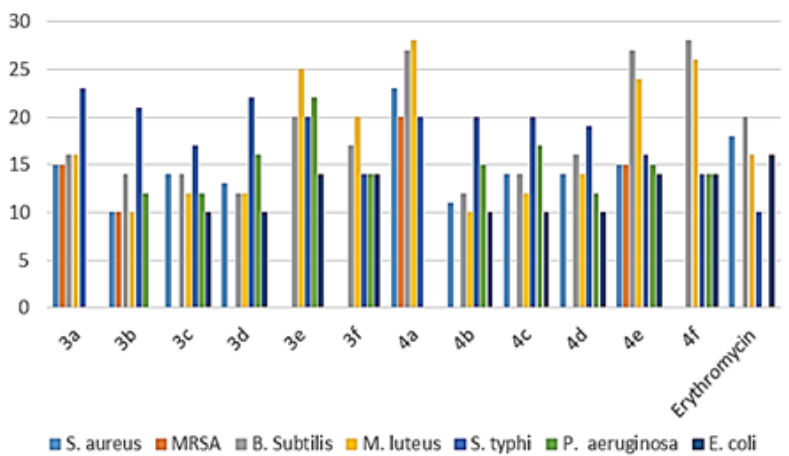

Corresponding author, email: mspchem99@gmail.com (M.S. Perumal).

Tel: +9197 15145939 . 


\section{Introduction}

The development of newer antibacterial and fungal drugs is necessary as the pathogens evolve resistance against the available drugs. Therefore, the synthesis of new and effective antimicrobial drugs become very important as many research programs have been directed toward the design of newer agents. Azomethines have potential for both chemical and biological activity [1-5], which is due to the presence of carbon nitrogen double bond. Azomethine and aminomethyl phenol derivatives represent one of the most biologically active classes of compounds, possessing a wide spectrum of activities such as antihyperglycemic [6], estrogenic and cytotoxic activities [7-9], anticancer [10], diuretic [11], and antiparasitic [12] activities. However, very limited literatures are available for the antimicrobial activities of aminomethyl phenol derivatives [13].

In this work, we synthesized series of azomethine and aminomethyl phenol derivatives possessing different substituents. The antimicrobial activities of the synthesized material was also assessed. The results showed that most of the synthesized molecules exhibited potent antimicrobial activity.

\section{Experimental}

\section{General procedure for the synthesis of azomethines}

$8.19 \mathrm{mmol}$ of aniline, $10 \mathrm{~mL}$ of dry ethanol, and $8.19 \mathrm{mmol}$ of salicylaldehyde were mixed at $0{ }^{\circ} \mathrm{C}$. The mixture was stirred for $10 \mathrm{~min}$. Then, it was heated upto $70^{\circ} \mathrm{C}$ and kept for $6 \mathrm{~h}$. The progress of the reaction was monitored by TLC, after the complete conversion of starting materials, the reaction mixture was cooled down to room temperature and formed precipitate was filtered off. Then it was washed with chilled ethanol $(2 \times 10 \mathrm{~mL})$ and dried under vacuum. The crude material was recrystallized using hot ethanol, affording the desired product as a solid.

\section{2-((E)-(phenylimino)methyl)phenol 3a}

Pale yellow crystals, yield 87\%, mp 51-52 ${ }^{\circ} \mathrm{C}$, IR (KBr) $\left(v_{\max } / \mathrm{cm}^{-1}\right): 3436,3054,1615,1483,1274$, 896 and 754. ${ }^{1} \mathrm{H}$ NMR (300 MHz, DMSO- $\left.d_{6}\right): \delta 13.07$ (s, 1H), $8.94(\mathrm{~s}, 1 \mathrm{H}), 7.64(\mathrm{~d}, J=7.6 \mathrm{~Hz}, 1 \mathrm{H}), 6.99-$ $6.94(\mathrm{~m}, 2 \mathrm{H}), 7.30-7.27$ (m, 1H), 7.65-7.31 (m, 5H). ${ }^{13} \mathrm{C}$ NMR (75 MHz, DMSO-d $): \delta 164,160.7,148.5$, 133.7, 133, 129.9, 127.4, 121.8, 119.7, 119.5, 117. MS/APCI $(\mathrm{m} / \mathrm{z}): 198\left(\mathrm{M}^{+}+\mathrm{H}\right)$. 


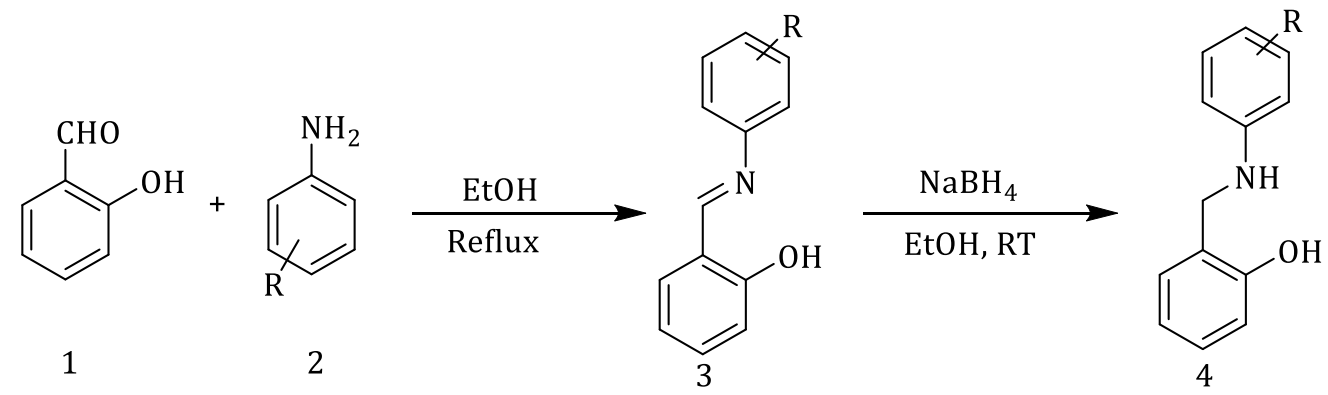

Scheme 1. synthesis of azomethines 3 and their aminomethyl phenols 4 .

Table 1. Preparation of azomethines 3 and their aminomethyl phenols 4.

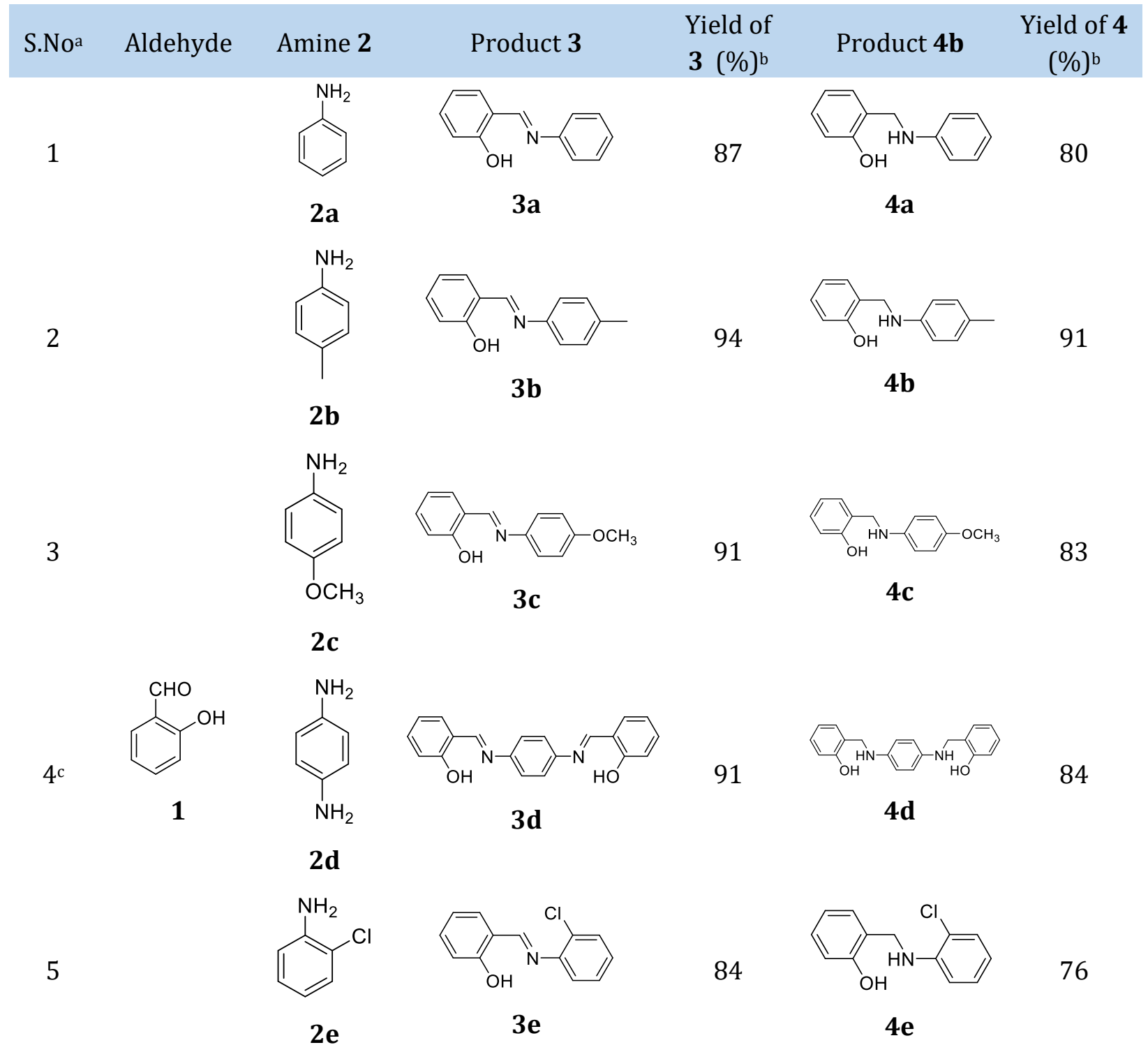


6

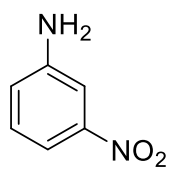

2f

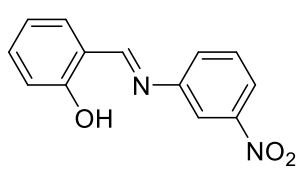

3f
89

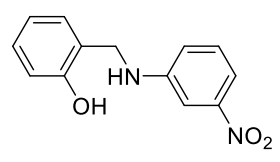

82

a To the formed azomethine ( $1 \mathrm{eq})$ in dry ethanol $(10 \mathrm{vol})$ sodium borohydride $(1.0 \mathrm{eq})$ was added in portions over a period of $20 \mathrm{~min}$ at $0{ }^{\circ} \mathrm{C}$ under $\mathrm{N}_{2}$ atmosphere. To the formed azomethine ( $\left.1 \mathrm{eq}\right)$ in dry ethanol (10 vol) sodium borohydride $\left(1.0 \mathrm{eq}\right.$ ) was added in portions over a period of $20 \mathrm{~min}$ at $0{ }^{\circ} \mathrm{C}$ under $\mathrm{N}_{2}$ atmosphere

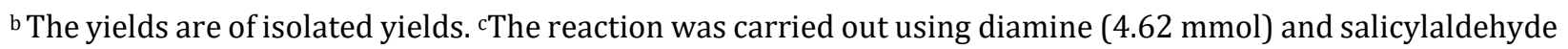
(18.49 mmol)

\section{General procedure for the synthesis of aminomethyl phenol}

To a stirred suspension of the imine (1 eq) in dry ethanol (10 vol), sodium borohydride (1 eq) was added in portions over a period of $20 \mathrm{~min}$ at $0{ }^{\circ} \mathrm{C}$ under $\mathrm{N}_{2}$ atmosphere. Then, the suspension was dissolved to get clear solution. The reaction mixture was kept at $0{ }^{\circ} \mathrm{C}$ for $2 \mathrm{~h}$. The progress of the reaction was monitored by TLC, after the complete conversion of starting materials, the white solid was filtered off. The white solid was washed with chilled ethanol $(2 \times 10 \mathrm{~mL})$ and dried under vacuum. The crude material was recrystallized by using hot ethanol, affording the desired product as white solid.

\section{2-(phenylaminomethyl) phenol $\mathbf{4 a}$}

White solid, yield 80\%, mp 107-108 ${ }^{\circ} \mathrm{C}$ [21-22], IR (KBr) ( $\left.v_{\max } / \mathrm{cm}^{-1}\right): 3640,3265,2865,1300$, 1251, 934 and 754. ${ }^{1} \mathrm{H}$ NMR (300 MHz, DMSO- $\left.d_{6}\right): \delta 7.14-6.96(\mathrm{~m}, 5 \mathrm{H}), 6.78-6.44(\mathrm{~m}, 4 \mathrm{H}), 4.14(\mathrm{~s}, 2 \mathrm{H})$; ${ }^{13}$ C NMR (75 MHz, DMSO- $\left.d_{6}\right): \delta 156,149.3,129.2,128.5,127.8,126.2,118.4,115.9,115.4,122.6,41.9$. MS/APCI $(m / z): 200\left(\mathrm{M}^{+}+\mathrm{H}\right)$.

\section{Results and Discussion}

The azomethine [14-20] and aminomethyl phenol derivatives [21-24] were synthesized by following a well-established protocol. The protocol is shown in Scheme 1. These derivatives were designed in such a way to have electron releasing and electron withdrawing groups in the amine part. The aminomethyl phenols 4 were prepared in large quantities through condensation of salicylaldehyde 1 with substituted anilines 2 (84-94\% yield) and subsequent reduction of the imine 3 using sodium borohydride-ethanol reagent system. The obtained yileds are presented in Table 1.

All the compounds were purified by recrystallization from ethanol. All the products were characterized using MS, IR, ${ }^{1} \mathrm{H}$ NMR, and ${ }^{13} \mathrm{C}$ NMR spectral techniques. It was reported in the literature 
that the $E$ isomer of imine 3 was formed [21-24] possibly due to the intramolecular $H$-bonding between hydroxyl group and nitrogen atom [25].

The results in Table 1 clearly showe that all of the reactions gave the desired products $\mathbf{3 a - f}$ and 4a-f in good to excellent yields. It was observed that the anilines possessing an electron-releasing group gave higher yields than those with an electron-withdrawing group.

In the NMR spectra, all of the compounds exhibited characteristic signals appropriately (See experimental section). For example, in the IR spectrum, 3a strong absorption at $1615 \mathrm{~cm}^{-1}$ corresponds to the stretching vibration of the $\mathrm{C}=\mathrm{N}$ group and $3336 \mathrm{~cm}^{-1}$ which relates to the $\mathrm{OH}$ group. In the ${ }^{1} \mathrm{H}$ NMR spectrum of 3a, singlets at $\delta 13.07$ and $8.94 \mathrm{ppm}$ correspond to $-\mathrm{HC}=\mathrm{N}$ - and $\mathrm{OH}$ protons, respectively. The downfield shift observed in $-\mathrm{HC}=\mathrm{N}$ - proton is due to the strong electronegativity of nitrogen. Meanwhile, the mass spectrum (MS/APCI) of 3a-f display a molecular ion peak at $m / z$ corresponding to $(\mathrm{M}+\mathrm{H})$. In the case of $\mathbf{4 a}$, a strong absorption at $3640 \mathrm{~cm}^{-1}$ corresponds to the stretching vibration of the $-\mathrm{OH}$ group and that at $3265 \mathrm{~cm}^{-1}$ relates to the stretching of -NH group. A singlet $\delta 4.14$ ppm observed in the ${ }^{1} \mathrm{H}$ NMR spectrum of 4 a corresponds to the benzylic proton. Meanwhile, the mass spectrum (MS/APCI) of $\mathbf{4 a - f}$ display a molecular ion peak at $m / z(\mathrm{M}+\mathrm{H})$.

\section{Antibacterial activity}

Biological activities of the azomethines and aminomethyl phenols were screened for antibacterial activity against four gram-positive bacterial strains including, Staphylococcus aureus, Methicillin resistant Staphylococcus aureus (MRSA), Bacillus subtilis, and Micrococcus luteus and three gramnegative pathogens Salmonella typhi, Pseudomonas aeruginosa, and Escherichiacoli. The biological acitivites were screened by Kirby-Bauer method [26], using disc diffusion technique at a concentration of $100 \mu \mathrm{g} / \mathrm{mL}$ with erythromycin as a standard drug. The zone of inhibition is compared in Table 2 and the corresponding clustered column chart is demonstrated in Figure 1. In general, a very good antibacterial activity was observed in all the compounds on the chosen microorganism.

According to the results of the antibacterial activity screening, all the synthesized compounds possess excellent antibacterial activity against two gram-positive bacterium Bacillus subtilis, and Micrococcus luteus, and one gram-negative bacterium viz. Salmonella typhi. The compounds $\mathbf{3 a}, \mathbf{3 b}$, 4a, and 4e were found to possess very good activity against Staphylococcus aureus, Methicillin resistant staphylococcus aureus (MRSA), Bacillus subtilis, Micrococcus luteus and Salmonella typhi. Azomethines 3c, 3d, and 3f, aminomethyl phenols 4b, 4c, 4d and $\mathbf{4 f}$ have showed moderate to good 
Table 2. Antibacterial activity of azomethines 3a-f and aminomethylphenols $\mathbf{4 a - f}$ against bacterial strains.

\begin{tabular}{cccccccc} 
& \multicolumn{4}{c}{ Zone of Inhibition in mm } & \multicolumn{4}{c}{ Gram Negative } \\
Compds & S. aureus & Gram Positive & B. & M. luteus & S. typhi & P. & E. coli \\
3a & 15 & 15 & 16 & 16 & 23 & - & - \\
3b & 10 & 10 & 14 & 10 & 21 & 12 & - \\
3c & 14 & - & 14 & 12 & 17 & 12 & 10 \\
3d & 13 & - & 12 & 12 & 22 & 16 & 10 \\
3e & - & - & 20 & 25 & 20 & 22 & 14 \\
3f & - & - & 17 & 20 & 14 & 14 & 14 \\
4a & 23 & 20 & 27 & 28 & 20 & - & - \\
4b & 11 & - & 12 & 10 & 20 & 15 & 10 \\
4c & 14 & - & 14 & 12 & 20 & 17 & 10 \\
$\mathbf{4 d}$ & 14 & - & 16 & 14 & 19 & 12 & 10 \\
4e & 15 & 15 & 27 & 24 & 16 & 15 & 14 \\
4f & - & - & 28 & 26 & 14 & 14 & 14 \\
Erythromycin & 18 & - & 20 & 16 & 10 & - & 16 \\
\hline
\end{tabular}

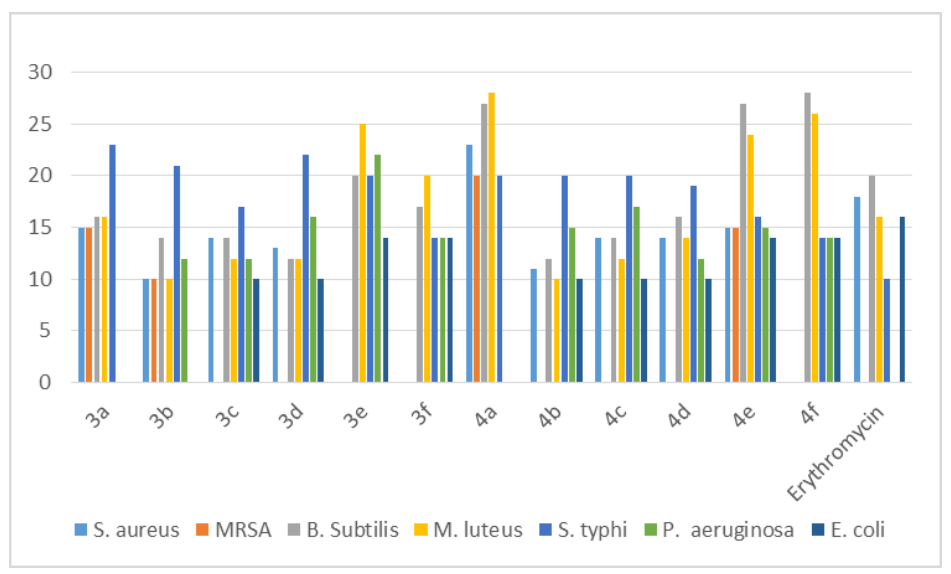

Figure 1. Clustered column chart for the antibacterial activity of azomethines 3a-f and aminomethylphenols 4a-f against bacterial strains

antibacterial activity against Staphylococcus aureus, Bacillus subtilis, Micrococcus luteus and Salmonella typhi. Pseudomonas aeruginosa, and Escherichia coli. 
Antifungal activity

The microbial organism Candida albicans is a fungal pathogen, causing wide range of diseases in susceptible persons [27]. These may be superficial infections to severe life threatening infections involving many essential organs. Recently, there has been a considerable increase in the incidence of disease attributable to Candida albicans, with the spread of AIDS, the widespread use of immunosuppressive therapy and prolonged survival of patients with critical illnesses [28]. Conventional therapy for the control of fungal infections relies on the use of ketoconazole drug. However, the emergence of $C$. albicans which isolates resistances to these drugs has serious implications for the continued success of these prescription anti-fungal compounds $[19,20]$. In the present study, antifungal activity of the synthesized azomethines 3a-f and aminomethyl phenols 4a-f were investigated against five fungal pathogens viz. Aspergillus niger, Fusarium oxysporum, Penicillium sp., Candida albicans, and Candida tropicalis. The disc diffusion technique was followed using KirbyBauer method [26], at a concentration of $100 \mu \mathrm{g} / \mathrm{mL}$ with ketoconozole as standard drug, and the obtained results are summarized in Table 3. The clustered column chart is revealed in Figure 2, indicating the fact that all the compounds have excellent antifungal activity against Cadida albicans species in particular. The compounds $\mathbf{3 a}$ and $\mathbf{4 a}$ have shown very good antifungal activity against all the five screened organisms. The azomethines $\mathbf{3 c}$ and $\mathbf{3 e}$ and the aminomethyl phenols $\mathbf{4 b - e}$ have exhibited moderate antifngal activity against Aspergillus niger. The compounds 3c and 3d have shown significant antifungal activity against Penicillium sp. Also, the azomethine derivative $\mathbf{3 e}$ and the aminomethylphenol derivatives $\mathbf{4 d}$ and $\mathbf{4 e}$ which have shown good activity against Candida tropicalis.

Table 3. Antifungal activity of azomethines 3a-f and aminomethylphenols $4 a-\mathbf{f}$ against bacterial strains.

\begin{tabular}{|c|c|c|c|c|c|}
\hline \multirow[b]{2}{*}{ Compds } & \multicolumn{4}{|c|}{ Zone of Inhibition in $\mathrm{mm}$} & \multirow[b]{2}{*}{$\begin{array}{l}\text { Candida } \\
\text { tropicalis }\end{array}$} \\
\hline & $\begin{array}{l}\text { Aspergillus } \\
\text { niger }\end{array}$ & $\begin{array}{l}\text { Fusarium } \\
\text { oxysporum }\end{array}$ & $\begin{array}{c}\text { Penicillium } \\
\text { sp. }\end{array}$ & $\begin{array}{l}\text { Candida } \\
\text { albicans }\end{array}$ & \\
\hline $3 a$ & 10 & 16 & 10 & 15 & 13 \\
\hline $3 \mathbf{b}$ & - & - & - & 10 & 15 \\
\hline $3 c$ & 12 & - & 10 & 10 & 8 \\
\hline $3 d$ & - & - & 10 & 17 & 15 \\
\hline $3 \mathbf{e}$ & 13 & - & - & 34 & - \\
\hline $3 f$ & - & - & - & 17 & - \\
\hline $4 a$ & 25 & 15 & 17 & 28 & 24 \\
\hline
\end{tabular}




\begin{tabular}{cccccc}
$\mathbf{4 b}$ & 12 & - & - & 10 & - \\
$\mathbf{4 c}$ & 12 & - & - & 10 & - \\
$\mathbf{4 d}$ & 10 & - & - & 25 & 13 \\
$\mathbf{4 e}$ & 11 & - & - & 27 & 15 \\
$\mathbf{4 f}$ & - & - & - & 20 & - \\
Ketoconazole & - & - & - & 24 & - \\
\hline
\end{tabular}

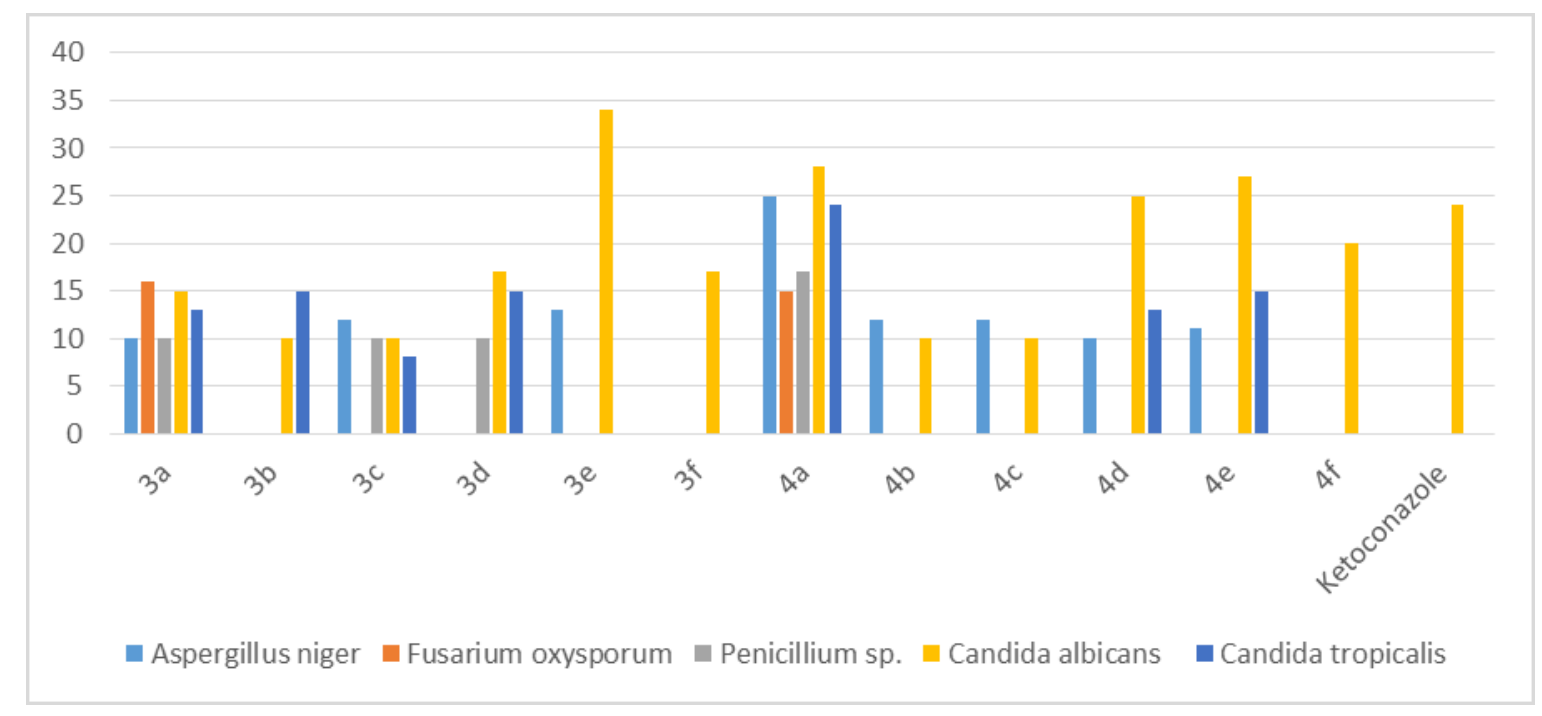

Figure 2. Clustered column chart for the antifungal activity of azomethines 3a-f and aminomethylphenols 4a-f against bacterial strains.

\section{Conclusion}

In this study, we have synthesized series of azomethine and aminomethyl phenol derivatives in good to excellent yields using mass, IR, ${ }^{1} \mathrm{H}$ NMR and ${ }^{13} \mathrm{C}$ NMR spectral techniques. In vitro antimicrobial activities of all the synthesized compounds 3a-f and $4 \mathbf{a}-\mathbf{f}$ were tested at a concentration of $100 \mathrm{ug} / \mathrm{mL}$. Among the synthesized compounds, the derivative $4 \mathbf{a}$ exhibited the best antimicrobial activity against gram positive bacterial strain such as S. aureus, MRSA, Bacillus subtilis, Micrococcus luteus and gram negative bacteria of Salmonella typhi. The aminomethyl phenol derivatives (4e and $\mathbf{4 f}$ ) containing electron withdrawing group were found to be the best in vitro anti-microbial activity against the gram positive bacterial strains such as Bacillus subtilis, Micrococcus luteus and gram negative bacterial strain Salmonella typhi, and fungal strain Candida albican. 


\section{Acknowledgements}

The authors would like to appreciate the UGC-BSR research start-up grant for newly recruited faculty at Assistant Professor Level and DST-SERB fast tract scheme for young scientists for financial support. We are also grateful to DST, New Delhi for support under “DST-FIST” Program.

\section{Disclosure Statement}

No potential conflict of interest was reported by the authors.

\section{Supporting Information}

Additional supporting information related to this article can be found, in the online version, at 10.33495/SAMI/AJGC/2019.4.7.

\section{References}

[1]. Lu J., Li C., Chai Y.F., Yang D.Y., Sun C.R. Bioorg. Med. Chem. Lett., 2012, 22:5744

[2]. Cheng L.X., Tang J.J., Luo H., Jin X.L., Dai F., Yang J., Qian Y.P., Li X.Z., Zhou B. Bioorg. Med. Chem. Lett., 2010, 20:2417

[3]. Franco D.C.Z., Carvalho G.S.G., Rocha P.R., Teixeira R.S., Silva A.D., Raposo N.R.B. Molecules, 2012, 17:11816

[4]. Niazi S., Javali C., Paramesh M., Sivaraja S. Int. J. Pharm. Pharm. Sci., 2010, 2:108

[5]. Suresh R., Kamalakkannan D., Ranganathan K., Arulkumaran R., Sundararajan R., Vijayakumar S., Sathiyamoorthi K., Mala V., Vanangamudi G., Thirumurthy K., Thirunarayanan G., Sakthinathan S.P., Mayavel P. Spectrochim. Acta, Part A. Molecul, Biomolecul, Spectros., 2013, 101:239

[6]. Misra S., Pandeya K.B., Tiwari A.K., Ali A.Z., Saradamani T., Agawane S.B., Madhusudana K. Med. Chem. Res., 2011, 20:1431

[7]. Iqbal A., Siddiqui H.L., Ashraf C.M., Bukhari M.H., Akram C.M. Chem. Pharm. Bull., 2007, 55:1070

[8]. Paula F.R., Jorge S.D., Almedia L.V., Pasqualoto K.F.M., Tavares L.C. Bioorg. Med. Chem., 2009, 17:2673

[9]. Shi L., Ge H.M., Tan S.H., Li H.Q., Song Y.C., Zhu H.L., Tan X.R. Eur. J. Med. Chem., 2007, 42:558

[10]. Kuzamin V.E., Artemenko A.G., Lozytska R.N., Fedtchouk A.S., Lozitsky V.P., Muratov E.N. Environ. Res., 2005, 16:219

[11]. Supuram C.T., Barboiu M., Luca C., Pop E., Brewster M.E., Dinculescu A. Eur. J. Med. Chem., 1996, 31:597

[12]. Rathelot P., Azas N., El-Kashef H., Delmas F., Di giorgio C., David P.T., Maldonado J., Vanelle P. Eur. J. Med. Chem., 2002, 37:671 
[13]. Babaev E.R. Petroleum chem., 2006, 46:206

[14]. Petrovic Z.D., Dorovic J., Simijonovic D., Petrovic V.P., Markovic Z. RSC Adv., 2015, 5:24094

[15]. Rahman F.U., Li Z.T., Ali A., Lin Y., Guo R., Wang W.K., Wang H., Zhang D.W. Dalton Trans., 2015, 44:9872

[16]. Zhang M., Luo F., Gong Y.J. Org. Chem., 2014, 79:1335

[17]. Dubey R.K., Singh A.P., Dwivedi N. Phosphorus, Sulfur Silicon Relat. Elem., 2012, 187:1038

[18]. Niu C., Zhao L., Ouyang J., Fang T., Deng X., Ma H., Zhang J., Na N., Han J. Langmuir, 2014, 30:2351

[19]. Das S., Das V.K., Saikia L., Thakur A.J. Green Chem. Lett. Rev., 2012, 5:457

[20]. Cimarelli C., Palmieri G., Volpini E. Tetrahedron, 2001, 57:6089

[21]. Tabane T.H., Singh G.S. Proc. Natl. Acad. Sci. India, Sect. A Phys. Sci., 2014, 84:517

[22]. Tang Z., Zhu Z., Xia Z., Liu H., Chen J., Xiao W., Ou X. Molecules, 2012, 17:8174

[23]. Kamble R.D., Gacche R.N., Hese S.V., Dawane B.S., Meshram R.J., Kote J.R. Med. Chem. Res., 2015, 24:1077

[24]. Karaka A., Elmali A., Unver H., Svoboda I. J. Mol. Struct., 2004, 702:103

[25]. Arod F., Gardon M., Pattison P., Chapuis G. Acta Crysta. A., 2005, 61:0317

[26]. Holt J.G., Krieg N.R., Sneath P.H.A., Staley J.T., Williams S.T. Bergey's Manual of Determinative Bacteriology, Williams and Wilkins Publisher, 9th Edition, Baltimore, 1994, p. 786

[27]. Faller P.M.A., Jones R.N., Messer S.A., Edmond M.B., Wenzel R.P. Diagn. Microbiol. Infect. Dis., 1998, 31:327

[28]. Lunel F.M.V., Meis J.F.G.M., Voss A. Diagn. Microbiol. Infect. Dis., 1999, 34:213

How to cite this manuscript: Sivakumar Matam, Prabakaran Kaliyan, Padmavathy Sethuramasamy, Seenivasa Perumal Muthu*. Synthesis and anti-microbial activities of azomethine and aminomethyl phenol derivatives. Asian Journal of Green Chemistry, 3(4) 2019, 508-517. DOI: 10.33495/SAMI/AJGC/2019.4.7 